\title{
PENGARUH LINGKUNGAN KERJA, ETOS KERJA, DAN DISIPLIN KERJA TERHADAP KINERJA KARYAWAN (STUDI KASUS PADA PEMKAB BONDOWOSO)
}

\author{
THE EFFECT OF WORK ENVIRONMENT, WORK ETHOS, AND \\ WORK DISCIPLINE TO EMPLOYEE PERFORMANCE \\ (CASE STUDY ON PEMKAB BONDOWOSO)
}

\author{
Yuli Yantika $^{1}$, Toni Herlambang ${ }^{2}$, Yusron Rozzaid ${ }^{3}$ \\ Fakultas Ekonomi Universitas Muhammadiyah Jember ${ }^{1,2,3}$ \\ E-mail : toniherlambang@unmuhjember.ac.id dan yusron.rozzaid@unmuhjember.ac.id
}

\begin{abstract}
BSTRAK
Tujuan penelitian ini untuk mengetahui pengaruh lingkungan kerja, etos kerja dan disiplin kerja terhadap kinerja karyawan. Metode yang digunakan dalam penelitian ini adalah metode kuantitatif. Data diperoleh dari penyebaran kuesioner sebanyak 104 responden yang juga sebagai populasi penelitian. Teknik analisis data yang digunakan untuk menguji hipotesis ini adalah analisis regresi linear berganda yang mencakup Uji $F$, Uji T, Uji Hipotesis dan Koefisien Determinasi. Hasil penelitian Uji $\mathrm{T}$ menyatakan bahwa: lingkungan kerja (X1) mempunyai pengaruh terhadap kinerja karyawan (Y1), etos kerja (X2) mempunyai pengaruh terhadap kinerja karyawan (Y1), disiplin kerja (X3) mempunyai pengaruh yang signifikan terhadap kinerja karyawan (Y1), lingkungan kerja (X1), etos kerja (X2), disiplin kerja (X3) mempunyai pengaruh secara simultan terhadap kinerja karyawan (Y1), lingkungan kerja (X1), etos kerja (X2) dan disiplin kerja (X3) secara bersama-sama mempunyai pengaruh signifikan terhadap efektifitas kinerja karyawan (Y1). Hasil Uji F hitung variabel lingkungan kerja (X1), etos kerja (X2) dan disiplin kerja (X3) dengan signifikan $0.000<\alpha=0.05$ serta bertanda positif menunjukkan bahwa secara simultan berpengaruh terhadap kinerja karyawan.
\end{abstract}

Kata Kunci: lingkungan kerja, etos kerja, disiplin kerja, kinerja karyawan

\begin{abstract}
This research is intended to know the influence of work environment, hard worker, and disclipne of employees. The method that is used in this research is quantitative method. The data is taken from questionnaires spread as much 104 respondent that is also as the research population. The technique of data anaysis which is used to test this hypothesis is regression linear double analysis include test of $\mathrm{F}$, test of $\mathrm{T}$, test of hypothesis and determination coefficient.

The results of the T test study stated that: work environment (X1) has an effect on employee performance (Y1), work ethic (X2) has an effect on employee performance (Y1), work discipline (X3) has a significant effect on employee performance (Y1), work environment (X1), work ethic (X2), work discipline (X3) has an effect simultaneously on employee performance (Y1), work environment (X1), work ethic (X2) and work discipline (X3) together have a significant influence on the effectiveness of employee performance (Y1).Result of test $\mathrm{F}$ count of work environment variable (X1), work ethic (X2) and work discipline (X3) with significant $0.000<\alpha=0.05$ and positive sign showed that simultaneously affect to employee performance.
\end{abstract}

Keywords: . work environment, work ethic, work discipline, employee performance 


\section{PENDAHULUAN}

Lingkungan kerja merupakan salah satu faktor penting dalam menciptakan kinerja karyawan. Karena lingkungan kerja mempunyai pengaruh langsung terhadap karyawan dalam menyelesaikan pekerjaan yang pada akhirnya akan meningkatkan kinerja organisasi. Suatu kondisi Lingkungan kerja dikatakan baik apabila karyawan dapat melaksanakan kegiatan secara optimal, sehat, aman, dan nyaman. Oleh karena itu penentuan dan penciptaan lingkungan kerja yang baik akan sangat menentukan keberhasilan pencapaian tujuan organisasi. Lingkungan kerja adalah keseluruhan sarana dan prasarana yang ada disekitar karyawan yang sedang melakukan pekerjaan itu sendiri (Rivai, 2006:165). Lingkungan kerja ini akan meliputi, fasilitas kerja, kebersihan, pencahayaan dan ketenangan. Menurut Nitisemito (2008:183) lingkungan kerja adalah segala yang ada dilingkungan sekitar para pekerja dan yang dapat memengaruhi dirinya dalam menjalankan tugas-tugas yang dibebankan kepadanya, misalnya kebersihan, musik, dan lain-lain. Hasil penelitian Anggy Henly Kumajas (2016) menyatakan lingkungan kerja berpengaruh signifikan terhadap kinerja karyawan, sedangkan hasil penelitian Novika Damayanti (2017) menyatakan lingkungan kerja berpengaruh signifikan terhadap kinerja karyawan.

Etos kerja adalah sikap yang muncul atas kehendak dan kesadaran sendiri yang didasari oleh sistem orientasi nilai budaya terhadap kerja (Sukardewi, 2013:3). Etos dibentuk oleh berbagai kebiasaan, pengaruh budaya, serta sistem nilai yang diyakininya (Tasmara, 2002:15). Hasil penelitian Stela Timbuleng (2015) menyatakan etos kerja secara simultan berpengaruh positif dan signifikan terhadap kinerja karyawan sedangkan secara parsial etos kerja tidak berpengaruh terhadap kinerja karyawan.

Selain etos kerja, disiplin kerja yang baik mencerminkan besarnya rasa tanggung jawab seseorang terhadap tugas-tugas yang diberikan kepadanya. Hal ini mendorong gairah kerja, semangat kerja dan terwujudnya tujuan organisasi, karyawan dan masyarakat. Kedisiplinan dapat diartikan bilamana karyawan selalu datang dan pulang tepat pada waktunya, mengerjakan semua pekerjaannya dengan baik, mematuhi semua peraturan perusahaan dan norma sosial yang berlaku (Fathoni, 2006:126). Hasil penelitian Titisari (2016) menyatakan bahwa disiplin kerja mempunyai pengaruh yang signifikan terhadap performa perusahaan.

Salah satu hal yang harus diperhatikan dalam pelaksanaan pekerjaan dalam suatu organisasi yaitu kinerja karyawan. Peningkatan kerja karyawan menempuh beberapa cara 
misalnya melalui pendidikan, pelatihan, pemberian kompensasi yang layak menciptakan lingkungan kerja yang kondusif, pemberian motivasi dan penetapan disiplin kerja yang baik. Perusahaan akan sulit mencapai tujuannya jika para karyawan di perusahaan tersebut tidak memiliki kinerja yang baik. Dalam usaha untuk mencapai suatu tujuan perusahaan diperlukan adanya karyawan yang penuh kesadaran, kesetiaan, ketaatan, disiplin dan bertanggung jawab atas segala pekerjaan yang diberikan dan telah dikerjakan. Kinerja karyawan yang optimal adalah gambaran dari sumber daya manusia yang berkualitas. Kinerja ini mencerminkan keberhasilan dari diri seseorang

Pemerintah Kabupaten adalah badan yang berfungsi membantu Bupati selaku Kepala Daerah dalam menentukan kebijaksanaan di bidang perencanaan pembangunan daerah serta penilaian atas pelaksanaannya. Berikut Data penilaian kinerja karyawan pada PEMKAB Bondowoso Tahun 2017 ditunjukkan pada Table 1.

Tabel 1: Data penilaian kinerja karyawan pada PEMKAB Bondowoso Tahun 2017.

\begin{tabular}{|l|l|c|c|}
\hline No & \multicolumn{1}{|c|}{ Unsur-unsur } & Nilai & Keterangan \\
\hline 1. & Kesetiaan & 92 & Amat Baik \\
\hline 2. & Prestasi kerja & 82 & Baik \\
\hline 3. & Tanggung jawab & 82 & Baik \\
\hline 4. & Ketaatan & 82 & Baik \\
\hline 5. & Kejujuran & 82 & Baik \\
\hline 6. & Kerjasama & 82 & Baik \\
\hline 7. & Prakarsa & 82 & Baik \\
\hline 8. & Kepemimpinan & 667 & Baik \\
\hline & Jumlah & $83,38 \%$ & Baik \\
\hline & Rata-Rata & Baik \\
\hline
\end{tabular}

Sumber: Data Penilaian kinerja karyawan pada PEMKAB Bondowoso Tahun 2017.

Dari Tabel 1. peneliti menyimpulkan bahwa rata-rata kinerja karyawan pada PEMKAB Bondowoso sudah baik pada tahun 2017. Hal ini dapat dilihat pada kinerja karyawan indikator yang digunakan mencangkup, kesetiaan, prestasi kerja, tanggung jawab, ketaatan, kejujuran, kerjasama, prakarsa dan kepemimpinan. Keberadaan Pemerintah kabupaten ini menjadi sangat penting dengan perkembangannya dalam proses perencanaan dan pelaksanaan pemrintahan di kabupaten. Dari uraian diatas maka rumusan masalahnya adalah sebagai: 
1. Apakah Lingkungan kerja berpengaruh signifikan terhadap kinerja karyawan pada PEMKAB Bondowoso?

2. Apakah Etos kerja berpengaruh signifikan terhadap kinerja karyawan pada PEMKAB Bondowoso?

3. Apakah Disiplin kerja berpengaruh signifikan terhadap kinerja karyawan pada PEMKAB Bondowoso?

\section{TINJAUAN PUSTAKA}

\section{Lingkungan Kerja}

Lingkungan kerja adalah keseluruhan sarana dan prasarana yang ada disekitar karyawan yang sedang melakukan pekerjaan itu sendiri (Rivai, 2006:165). Lingkungan kerja ini akan meliputi, fasilitas kerja, kebersihan, pencahayaan dan ketenangan. Menurut Nitisemito (2008:183) lingkungan kerja adalah segala yang ada di lingkungan sekitar para pekerja dan yang dapat mempengaruhi dirinya dalam menjalankan tugastugas yang dibebankan kepadanya, misalnya kebersihan, musik, dan lain-lain.

\section{Etos Kerja}

Etos kerja adalah sikap yang muncul atas kehendak dan kesadaran sendiri yang didasari oleh sistem orientasi nilai budaya terhadap kerja (Sukardewi, 2013:3). Etos berasal dari bahasa Yunani, yaitu ethos yang artinya sikap, kepribadian, watak, karakter, serta keyakinan atas sesuatu. Sikap ini tidak saja dimiliki oleh individu, tetapi juga oleh kelompok bahkan masyarakat. Etos dibentuk oleh berbagai kebiasaan, pengaruh budaya, serta sistem nilai yang diyakininya (Tasmara, 2002:15).

\section{Disiplin Kerja}

Disiplin kerja yang baik mencerminkan besarnya rasa tanggung jawab seseorang terhadap tugas-tugas yang diberikan kepadanya. Hal ini mendorong gairah kerja, semangat kerja dan terwujudnya tujuan organisasi, karyawan dan masyarakat. Oleh karena itu, setiap manajer selalu berusaha agar bawahannya mempunyai kedisiplinan yang baik. Seorang manajer dikatakan efektif dalam kepemimpinannya, jika para bawahannya berdisiplin baik. Kedisiplinan dapat diartikan bilamana karyawan selalu datang dan pulang tepat pada waktunya, mengerjakan semua pekerjaannya dengan baik, 
mematuhi semua peraturan perusahaan dan norma sosial yang berlaku (Fathoni, 2006:126).

\section{Kinerja Karyawan}

Marihot Tua Efendi (2002) berpendapat bahwa kinerja merupakan hasil kerja yang dihasilkan oleh pegawai atau perilaku nyata yang ditampilkan sesuai peranannya dalam organisasi. Kinerja juga berarti hasil yang dicapai seseorang baik kualitas maupun kuantitas sesuai dengan tanggung jawab yang diberikan kepadanya. Selain itu kinerja seseorang dipengaruhi oleh tingkat pendidikan, inisiatif, pengalaman kerja, dan motivasi karyawan. Hasil kerja seseorang akan memberikan umpan balik bagi orang itu sendiri untuk selalu aktif melakukan pekerjaannya secara baik dan diharapkan akan menghasilkan mutu pekerjaan yang baik pula. Pendidikan mempengaruhi kinerja seseorang karena dapat memberikan wawasan yang lebih luas untuk berinisiatif dan berinovasi dan selanjutnya berpengaruh terhadap kinerjanya. Evaluasi kinerja karyawan biasanya dilakukan secara berkala dalam interval waktu tertentu (Azhad. dkk., 2015)

\section{Hipotesis Penelitian}

Berdasarkan teori dan penelitian terdahulu, maka hipotesis yang diajukan dalam penelitian ini adalah sebagai berikut:

1. $\mathrm{H}_{1}$ : Lingkungan kerja berpengaruh signifikan terhadap kinerja karyawan pada PEMKAB Bondowoso.

2. $\mathrm{H}_{2}$ : Etos kerja berpengaruh signifikan terhadap kinerja karyawan pada PEMKAB Bondowoso.

3. $\mathrm{H}_{3}$ : Disiplin kerja berpengaruh signifikan terhadap kinerja karyawan pada PEMKAB Bondowoso

4. $\mathrm{H}_{4}$ : Lingkungan kerja, etos kerja, dan disiplin kerja berpengaruh simultan terhadap kinerja karyawan pada PEMKAB Bondowoso

\section{METODE PENELITIAN}

Penelitian yang dilaksanakan pada karya ilmiah ini adalah penelitian kausal. Kausal merupakan riset yang bertujuan utama membuktikan hubungan sebab-akibat atau hubungan mempengaruhi dan dipengaruhi dari variabel-variabel yang diteliti (Margono, 2010). Populasi dalam penelitian ini adalah 104 karyawan di PEMKAB Bondowoso. 
Tehnik pengambilan sampel dalam penelitian ini menggunakan tehnik non probability sampling yaitu dnegan pendekatan Accidental Sampling atau sampling kebetulan. Accidental sampling adalah tehnik penentuan sampel berdasarkan kebetulan, yaitu siapa saja yang secara kebetulan bertemu dengan peneliti dapat digunakan sebagai sampel (Sugiyono, 2010).

Pengambilan sampel dengan pertimbangan faktor keterbatasan yang tidak memungkinkan seluruh populasi untuk diteliti. Untuk menentukan beberapa sampel yang dibutuhkan, maka digunakan rumus Slovin. Populasi dalam penelitian ini berjumlah sebesar 104 karyawan. Sampel yang digunkan adalah 51 responden yang diperoleh dari rumus Slovin.

Berkaitan dengan penelitian ini, variabel penelitian terbagi menjadi dua yang terdiri dari variabel dependent dan variabel independent, sebagai berikut :

1. Variabel independent atau variabel bebas adalah variabel yang mempengaruhi atau yang menjadi sebab berubahnya atau timbulnya variabel terikat (Sugiono, 2008), variabel bebas dalam penelitian ini antara lain:

a. Lingkungan Kerja (X1)

Lingkungan kerja adalah keseluruhan sarana dan prasarana yang ada disekitar karyawan yang sedang melakukan pekerjaan itu sendiri (Rivai, 2006:165). Beberapa hal satu yang menjadi indikator dalam lingkungan kerja menurut Sedarmayanti (2007) adalah sebagai berikut:

1. Tata letak ruang kerja

2. Kebersihan

3. Suara dan Suhu

4. Peralatan kantor

5. Hubungan sesama rekan kerja

6. Hubungan kerja antara atasan dan bawahan

b. Etos Kerja (X2)

Etos kerja adalah sikap yang muncul atas kehendak dan kesadaran sendiri yang didasari oleh sistem orientasi nilai budaya terhadap kerja (Sukardewi, 2013:3). Indikator etos kerja, untuk mengetahui apakah etos kerja atau semangat kerja karyawan di perusahaan itu tinggi atau rendah adalah sebagai berikut:

1. Komunikasi antar karyawan

2. Penguasaan pekerjaan atau keterampilan 
3. Kepatuhan bekerja terhadap perusahaan

4. Kesungguhan dalam bekerja

c. Disiplin Kerja (X3)

Disiplin kerja yang baik mencerminkan besarnya rasa tanggung jawab seseorang terhadap tugas-tugas yang diberikan kepadanya. Hal ini mendorong gairah kerja, semangat kerja dan terwujudnya tujuan organisasi, karyawan dan masyarakat.

Indikator yang mempengaruhi tingkat kedisiplinan karyawan suatu organisasi, diantaranya Hasibuan (2009):

1. Kehadiran tepat waktu

2. Ketepatan waktu penyelesaian pekerjaan

3. Mentaati peraturan kerja

4. Menjalankan prosedur kerja

5. Menggunakan peralatan kantor dengan baik

Variabel terikat (dependen) adalah variable yang dipengaruhi oleh variable bebas (independen). Variabel terikat yang digunakan dalam penelitian ini adalah Kinerja Karyawan (Y). Kinerja karyawan pada BAPPEDA Kabupaten Bondowoso adalah tingkat hasil kerja dalam pencapaian persyaratan pekerjaan yang diberikan, kualitas kerja, kuantitas kerja, dan ketepatan (Fuad Mas'ud, 2004):

1. Waktu untuk menyelesaikan pekerjaan

2. Kuantitas hasil pekerjaan

3. Kemampuan dalam menyelesaikan pekerjaan

4. Ketepatan dalam mengerjakan pekerjaan

\section{HASIL DAN PEMBAHASAN}

\section{Gambaran Umum Responden}

Responden dalam penelitian ini adalah seluruh karyawan PEMKAB Bondowoso. Jumlah responden yang menjadi sampel dalam penelitian ini sebesar 51 orang, dipilih berdasarkan teknik pengambilan sampel, dengan perhitungan jumlah sampel menggunakan rumus Slovin. Karakteristik responden dalam penelitian ini dikelompokkan berdasarkan usia, jenis kelamin dan masa kerja.

Berdasarkan hasil perhitungan dapat diketahui bahwa responden berusia antara usia kurang dari 18 tahun jumlah 9 orang atau 9,5\%, selanjutnya 18-25 tahun yaitu sebanyak 27 orang atau $27,2 \%$ dan usia lebih dari 50 tahun sebanyak 15 orang atau 
15,8\%. Berdasarkan hasil perhitungan atas masa kerja dapat diketahui bahwa responden yang masa kerjanya 5-15 tahun berjumlah 25 orang atau 25,9\%, selanjutnya yang masa kerjanya dari 16-25 tahun berjumlah 26 orang atau 26,8\%. Berdasarkan perhitungan dari aspek jemis kelamin dapat diketahui bahwa dari 51 responden sebagian besar berjenis kelamin laki-laki yaitu sebanyak 30 orang atau $80 \%$ dan sisanya berjenis kelamin perumpuan yaitu sebanyak 21 orang atau $20 \& \%$.

\section{Hasil Uji Validitas}

Hasil perhitungan uji validitas menunjukkan bahwa bahwa seluruh variable menunjukkan bahwa korelasi antara masing-masing indikator terhadap total skor memiliki nilai signifikanai $<0,05$ sehingga dapat disimpulkan bahwa semua item pernyataan dinyatakan valid. Hasil perhitungan uji reliabilitas terlihat hasil uji reliabilitas tersebut menunjukkan bahwa nilai cronbach's Alpha yakni 0,815, 0,793, 0,802, 0,825, >0,60 sehingga item-item pada masing-masing variabel tersebut layak digunakan sebagai alat ukur, dan kuesioner dinyataka handal atau reliable.

\section{Analisis Regresi Linier Berganda}

Analisis ini digunakan dengan melibatkan dua atau lebih variabel bebas anatara variabel dependen $(\mathrm{Y})$ dan variabel independen $\left(\mathrm{X}_{1}, \mathrm{X}_{2}\right.$, dan $\mathrm{X}_{3}$,). Cara ini digunakan untuk mengetahui kuatnya hubungan anatara beberapa variabel bebas secara serentak terhadap variabel terkait dan dinyatakan dengan rumus Sugiyono (2010).

Tabel 2. Hasil Analisis Regresi Linier Berganda

\begin{tabular}{clc}
\hline No & \multicolumn{1}{c}{ Variabel } & Koefisien Regresi \\
\hline 1 & Konstanta & .182 \\
2 & Lingkungan Kerja (X1) & 0,379 \\
3 & Etos Kerja (X2) & 0,282 \\
4 & Disiplin Kerja (X3) & 0,363 \\
\hline
\end{tabular}

Sumber: Data Yang Diolah, 2018

Berdasarkan tabel 2. dapat diketahui persamaan regresi yang terbentuk adalah:

$\mathrm{Y}=\mathrm{a}+\mathrm{b}_{1} \mathrm{X}_{1}+\mathrm{b}_{2} \mathrm{X}_{2}+\mathrm{b}_{3} \mathrm{X}_{3}+\mathrm{e}$

$\mathrm{Y}=.182+0,379 \mathrm{X} 1+0,282 \mathrm{X} 2+0,363 \mathrm{X} 3+\mathrm{e}$

\section{Uji Hipotesis}

Uji t digunakan untuk menguji seberapa jauh pengaruh satu variabel independen secara individual dan menerangkan variasi variabel dependen Ghozali (2009). Dalam 
penelitian ini uji t digunakan untuk mengetahui apakah variabel lingkungan kerja, etos kerja, dan disiplin kerja berpengaruh secara parsial terhadap variabel dependen yaitu kinerja karyawan. Dengan signifikan $5 \%(\alpha=0,05$

Tabel 3. Hasil Uji T

\begin{tabular}{|c|c|c|c|c|c|c|}
\hline No & Variabel & Sig. & A & $\mathrm{t}$ hitung & $\mathrm{t}_{\text {tabel }}$ & $\begin{array}{c}\text { Keteranga } \\
\mathbf{n}\end{array}$ \\
\hline 1 & $\begin{array}{l}\text { Lingkungan kerja } \\
\text { (X1) }\end{array}$ & 0,002 & $<0,05$ & 3,319 & 1,6779 & Signifikan \\
\hline 2 & Etos kerja (X2) & 0,006 & $<0,05$ & 2,849 & 1,6779 & Signifikan \\
\hline 3 & Disiplin kerja (X3) & 0,002 & $<0,05$ & 3,213 & 1,6779 & Signifikan \\
\hline
\end{tabular}

Sumber: Data Yang Diolah, 2018

Dari tabel 3. diketahui perbandingan antara taraf signifikansi dengan signifikansi tabel adalah sebagai berikut:

a. Variabel lingkungan kerja (X1) memiliki nilai $t$ hitung $(3,319)>t$ tabel $(1,6779)$ dan signifikasi 0,002 < 0,05, maka Ho ditolak dan Ha terima, yang berarti lingkungan kerja berpengaruh signifikan terhadap variable kinerja karyawan (Y). dapat disimpulkan bahwa, jika terjadi peningkatan pada variable lingkungan kerja maka hal tersebut akan meningkatkan kinerja karyawan.

b. Variabel etos kerja (X2) memiliki nilai $t$ hitung $(2,849)>t$ tabel $(1,6779)$ dan signifikasi 0,006 < 0,05, maka Ho ditolak dan Ha terima, yang berarti etos kerja berpengaruh signifikan terhadap variable kinerja karyawan (Y). dapat disimpulkan bahwa, jika terjadi peningkatan pada variable etos kerja maka hal tersebut akan meningkatkan kinerja karyawan .

c. $\mathrm{X}_{2}=$ Etos kerja, Koefisien bernilai positif artinya hubungan positif antara etos kerja, dengan kinerja karyawan, semakin tinggi etos kerjanya maka akan meningkatkan kinerja karyawan.

d. $X_{3}=$ Disiplin kerja, Koefisien bernilai positif artinya hubungan positif antara disiplin kerja dengan kinerja karyawan, semakin baik disiplin kerja maka akan meningkatkan kinerja karyawan.

Untuk menguji pengaruh variabel bebas secara bersama-sama diuji dengan menggunakan uji F. Pengujian dilakukan dengan melihat statistik $F_{\text {hitung }}$ dengan nilai statistik $\mathrm{F}_{\text {tabel }}$ dan taraf signifikansi ( $p$-value), jika taraf signifikansi yang dihasilkan dari perhitungan di bawah 0,05 maka hipotesis diterima, sebaliknya jika taraf signifikansi 
hasil hitung lebih besar dari 0,05 maka hipotesis ditolak (Ghozali, 2013:97). Nilai $F_{\text {tabel }}$ didapatkan dari $\mathrm{df}_{1}=\mathrm{k}-1(4-1)$ sama dengan 3 dan $\mathrm{df}_{2}=\mathrm{n}-\mathrm{k}(51-4)$ sama dengan 47. Dimana $\mathrm{n}$ adalah jumlah sampel dan $\mathrm{k}$ adalah jumlah variabel. Jadi untuk melihat $\mathrm{F}_{\text {tabel }}$ caranya dengan melihat tabel $\mathrm{df}_{1}$ tabel ke 3 dan $\mathrm{df}_{2}$ baris ke 47 yaitu 2.8024

\section{Tabel 4. Hasil Uji F}

\begin{tabular}{cccc}
\hline No & \multicolumn{2}{c}{ Kriteria } & Keterangan \\
\hline \multirow{2}{*}{1} & $\mathrm{~F}_{\text {hitung }}$ & $\mathrm{F}_{\text {tabel }}$ & Signifikan \\
& $(23.626)$ & $(2,8024)$ & \\
2 & Nilai signifikansi & Taraf signifikansi & Signifikan \\
\hline
\end{tabular}

Sumber; Data Diolah, 2018

Berdasar tabel 44 dapat dilihat bahwa $F_{\text {hitung }}>F_{\text {tabel }}(23.626>2,8024)$ maka lingkungan kerja, etos kerja, dan disiplin kerja mempunyai pengaruh signifikan terhadap kinerja karyawan pada tingkat signifikan 5\%, dalam hal ini $\mathrm{h}_{0}$ ditolak. Sehingga, hipotesis yang menyatakan lingkungan kerja, etos kerja, dan disiplin kerja mempunyai pengaruh signifikan terhadap kinerja karyawan terbukti kebenarannya (Ha diterima).

\section{Koefisien Determinasi $\left(\mathbf{R}^{2}\right)$}

Koefisisen determinasi $\left(\mathrm{R}^{2}\right)$ pada intinya mengukur seberapa jauh kemampuan model dalam menerangkan variasi variable terikat. Dengan kata lain, Koefisisen determinasi ini digunakan untuk mengukur seberapa jauh variable- varibel bebas menerangkan variable terikatnya (Ghozali, 2009).

Tabel 5. Hasil uji Koefisien Determinasi (R2)

Kriteria Koefisien

R Square 0,576

Sumber : Data Yang Diolah, 2018,

Table 5. menunjukkan nilai Koefisisen determinasi (R2) sebesar 0,576. Nilai tersebut menunjukan besarnya proporsi atau presentase pengaruh variabel lingkungan kerja (X1), etos kerja (X2), disiplin kerja (X3), secara bersama-sama terhadap kinerja karyawan (Y), sedangkan sisanya sebesar dipengaruhi faktor lain yang tidak dimasukkan dalam model penelitian ini. 


\section{Pembahasan}

Berdasarkan dari hasil pengujian secara statistik dapat diketahui dengan jelas bahwa variable lingkungan ekrja, etos kerja, dan disiplin kerja berpengaruh secara positif terhadap kinerja karyawan. Penjelasan dari masing- masing variable adalah sebagai berikut:

\section{a. Pengaruh Lingkungan Kerja Terhadap Kinerja Karyawan}

Variabel lingkungan kerja (X1) memiliki nilai $t_{\text {hitung }}(3,319)>t$ tabel $(1,6779)$ dan signifikasi 0,002 < 0,05, maka Ho ditolak dan Ha terima, yang berarti lingkungan kerja berpengaruh signifikan terhadap variable kinerja karyawan (Y). dapat disimpulkan bahwa, jika terjadi peningkatan pada variable lingkungan kerja maka hal tersebut akan meningkatkan kinerja karyawan. Lingkungan kerja merupakan salah satu faktor penting dalam menciptakan kinerja karyawan. Karena lingkungan kerja mempunyai pengaruh langsung terhadap karyawan dalam menyelesaikan pekerjaan yang pada akhirnya akan meningkatkan kinerja organisasi. Suatu kondisi Lingkungan kerja dikatakan baik apabila karyawan dapat melaksanakan kegiatan secara optimal, sehat, aman, dan nyaman. Oleh karena itu penentuan dan penciptaan lingkungan kerja yang baik akan sangat menentukan keberhasilan pencapaian tujuan organisasi. Sebaliknya apabila lingkungan kerja yang tidak baik akan dapat menurunkan motivasi serta semangat kerja dan akhirnya dapat menurunkan kinerja karyawan.

Lingkungan kerja adalah keseluruhan sarana dan prasarana yang ada disekitar karyawan yang sedang melakukan pekerjaan itu sendiri (Rivai, 2006:165). Lingkungan kerja ini akan meliputi, fasilitas kerja, kebersihan, pencahayaan dan ketenangan. Menurut Nitisemito (2008:183) lingkungan kerja adalah segala yang ada di lingkungan sekitar para pekerja dan yang dapat memengaruhi dirinya dalam menjalankan tugastugas yang dibebankan kepadanya, misalnya kebersihan, musik, dan lain-lain.

Lingkungan kerja dalam suatu perusahaan sangat penting untuk diperhatikan manajemen. Meskipun lingkungan kerja tidak melaksanakan proses produksi dalam suatu perusahaan, namun lingkungan kerja mempunyai pengaruh langsung terhadap para karyawan yang melaksanakan proses produksi tersebut. Menurut (Sunyoto, 2012:43) menyatakan lingkungan kerja adalah segala sesuatu yang ada disekitar para pekerja dan dapat mempengaruhi dirinya dalam menjalankan tugas-tugas yang dibebankan. Lingkungan kerja adalah segala sesuatu yang ada disekitar para pekerja atau karyawan yang dapat mempengaruhi kepuasan kerja karyawan dalam melaksanakan pekerjaannya 
sehingga akan diperoleh hasil kerja yang maksimal, dimana dalam lingkungan kerja tersebut terdapat fasilitas kerja yang mendukung karyawan dalam penyelesaian tugas yang bebankan kepada karyawan guna meningkatkan kerja karyawan dalam suatu perusahaan. Lingkungan kerja merupakan salah satu faktor yang mempengaruhi kinerja seorang karyawan. Seorang karyawan yang bekerja di lingkungan kerja yang mendukung dapat menghasilkan kinerja yang baik.

\section{b. Pengaruh Etos Kerja Terhadap Kinerja Karyawan}

Variabel etos kerja (X2) memiliki nilai $t$ hitung $(2,849)>t$ tabel $(1,6779)$ dan signifikasi $0,006<0,05$, maka Ho ditolak dan Ha terima, yang berarti etos kerja berpengaruh signifikan terhadap variable kinerja karyawan (Y). dapat disimpulkan bahwa, jika terjadi peningkatan pada variable etos kerja maka hal tersebut akan meningkatkan kinerja karyawan. Etos kerja adalah sikap yang muncul atas kehendak dan kesadaran sendiri yang didasari oleh sistem orientasi nilai budaya terhadap kerja (Sukardewi, 2013:3). Etos berasal dari bahasa Yunani, yaitu ethos yang artinya sikap, kepribadian, watak, karakter, serta keyakinan atas sesuatu. Sikap ini tidak saja dimiliki oleh individu, tetapi juga oleh kelompok bahkan masyarakat. Etos dibentuk oleh berbagai kebiasaan, pengaruh budaya, serta sistem nilai yang diyakininya (Tasmara, 2002:15).

Etos kerja merupakan seperangkat perilaku positif yang berakar pada keyakinan fundamental yang disertai komitmen total pada paradigma kerja yang integral (Sinamo, 2005:151). Etos kerja adalah totalitas kepribadian dirinya serta cara mengekspresikan, memandang, meyakini, dan memberikan makna pada sesuatu, yang mendorong dirinya untuk bertindak dan meraih amal yang optimal (Octarina 2013). Kesimpulan penulis bahwa etos kerja sikap, perilaku individu yang memihak sepenuhnya terhadap pekerjaan yang ia lakukan.

Etos Kerja merupakan fondasi dari sukses yang sejati dan otentik. Pandangan ini dipengaruhi oleh kajiannya terhadap studi-studi sosiologi sejak zaman Max Weber di awal abad ke-20 dan penulisan-penulisan manajemen dua puluh tahun belakangan ini yang semuanya bermuara pada satu kesimpulan utama,bahwa keberhasilan di berbagai wilayah kehidupan ditentukan olehperilaku manusia,terutama perilaku kerja. Sebagian orang menyebut perilaku kerja ini sebagai motivasi, kebiasaan (habit) dan budaya kerja. Sinamo dalam Novliadi (2009:6) lebih memilih menggunakan istilah etos karena menemukan bahwa kata etos mengandung pengertian tidak saja sebagai perilaku khas 
dari sebuah organisasi atau komunitas tetapi juga mencakup motivasi yang menggerakkan mereka, karakteristik utama, spirit dasar, pikiran dasar, kode etik, kode moral, kode perilaku, sikap-sikap, aspirasi-aspirasi, keyakinan-keyakinan, prinsipprinsip, dan standar-standar.

\section{c. Pengaruh Disiplin Kerja Terhadap Kinerja Karyawan}

Variabel disiplin kerja (X3) memiliki nilai $t$ hitung $(3,213)>t$ tabel $(1,6779)$ dan signifikasi $0,002<0,05$, maka Ho ditolak dan Ha terima, yang berarti disiplin kerja berpengaruh signifikan terhadap variable kinerja karyawan (Y). dapat disimpulkan bahwa, jika terjadi peningkatan pada variable disiplin kerja maka hal tersebut akan meningkatkan kinerja karyawan. Disiplin kerja yang baik mencerminkan besarnya rasa tanggung jawab seseorang terhadap tugas-tugas yang diberikan kepadanya. Hal ini mendorong gairah kerja, semangat kerja dan terwujudnya tujuan organisasi, karyawan dan masyarakat. Oleh karena itu, setiap manajer selalu berusaha agar bawahannya mempunyai kedisiplinan yang baik. Seorang manajer dikatakan efektif dalam kepemimpinannya, jika para bawahannya berdisiplin baik. Kedisiplinan dapat diartikan bilamana karyawan selalu datang dan pulang tepat pada waktunya, mengerjakan semua pekerjaannya dengan baik, mematuhi semua peraturan perusahaan dan norma sosial yang berlaku (Fathoni, 2006:126).

Hasibuan (2016:193) menyatakan kedisiplinan adalah kesadaran dan kedesiaan seseorang menaati semua peraturan perusahaan dan norma-norma sosial yang berlaku, semakin baik disiplin karyawan, semakin tinggi prestasi kerkkja yang dapat dicapainnya. Jadi seseorang akan bersedia mematuhi semua peraturan serta melaksanakan tugastugasnya, baik secara sekarela maupun karena terpaksa. Dan begitu juga Nawawi (2006:322) mengemukakan bahwa secara umum disiplin kerja merupakan suatu kondisi yang tercipta dan terbentuk melalui proses dari serangkaian perilaku yang menunjukan nilai-nalai ketaatan, kepatuhan, kesetiaan, dan ketertiban.

\section{KESIMPULAN}

Dari pengujian secara statistik yang telah dilakukan, maka dapat ditarik kesimpulan :

1. Lingkungan kerja berpengaruh positif dan signifikan terhadap kinerja karyawan PEMKAB Bondowoso. 
2. Etos kerja berpengaruh secara positif dan signifikan terhadap kinerja karyawan PEMKAB Bondowoso.

3. Disiplin kerja berpengaruh secara positif dan signifikan terhadap kinerja karyawan PEMKAB Bondowoso.

\section{DAFTAR PUSTAKA}

Azhad, M Naely, Anwar, Nurul Qomariah. 2015. Manajemen Sumberdaya Manusia. Jember. Cahaya Ilmu.

Efendi Marihot Tua, 2002. Manajemen Sumber Daya Manusia, Grasindo, Jakarta

Fathoni, 2006. Manajemen Sumber Daya Manusia, Rineka Cipta. Bandung.

Ghozali, 2009. “Aplikasi Analisis Multivariate dengan Program SPSS “. Semarang : UNDIP.

Ghozali, Imam. 2013. Aplikasi Analisis Multivariate dengan Program SPSS. Edisi Ketujuh. Semarang : Badan Penerbit Universitas Diponegoro.

Hasibuan, Malayu S.P. 2009. Manajemen Dasar, Pengertian, Dan Masalah. Jakarta: PT Bumi Aksara.

Hasibuan, Malayu S.P. 2012. "Manajemen Sumber Daya manusia”. Jakarta: PT Bumi Aksara.

Margono. 2010. Metodologi Penelitian Pendidikan. Jakarta: Rineka Cipta.

Mas'ud Fuad, 2004, "Survai Diagnosis Organisasional," Badan Penerbit Universitas Diponegoro, Semarang.

Nitisemito, 2008. Manajemen Personalia. Ghalia Indonesia, Jakarta.

Rivai, 2006. Manajemen Sumber Daya Manusia untuk Perusahaan : dari Teori Ke Praktik, Edisi Pertama, Penerbit PT. Raja Grafindo Persada, Jakarta.

Sinamo, Jansen. (2011). 8 Etos Kerja Profesional. Jakarta: Institut Dharma Mahardika. Sopiah, 2008, Manajemen Bisnis Ritel, Andi, Yogyakarta.

Sugiyono, (2010). Metode Penelitian Kuantitatif Kualitatif dan R\&D; Penerbit CV Alfabeta, Bandung.

Sugiyono, (2014). Metode Penelitian Pendidikan Pendekatan Kuantitatif, Kualitatif, dan $R \& D$. Bandung: Alfabeta. 
Sukardewi, 2013. Kontribusi Adversity Quotient (AQ) Etos Kerja dan Budaya Organisasi terhadap kinerja Guru SMA Negeri di kota Amlapura. Jurnal Akutansi Pascasarjana Universitas Syiah Kuala Vol 4.

Tasmara, (2002). Membudayakan Etos Kerja Islami. Jakarta: Gema Insani. 